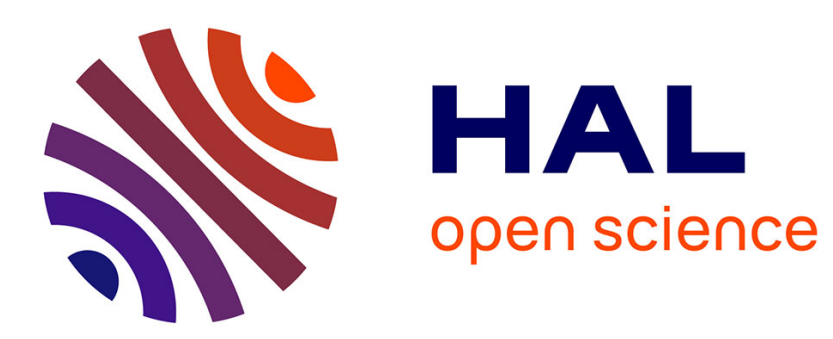

\title{
Social studies of volcanology: knowledge generation and expert advice on active volcanoes
}

\author{
Amy Donovan, Clive Oppenheimer, Michael Bravo
}

\section{To cite this version:}

Amy Donovan, Clive Oppenheimer, Michael Bravo. Social studies of volcanology: knowledge generation and expert advice on active volcanoes. Bulletin of Volcanology, 2012, 74 (3), pp.677-689. 10.1007/s00445-011-0547-z . insu-00691620

\section{HAL Id: insu-00691620 https://hal-insu.archives-ouvertes.fr/insu-00691620}

Submitted on 9 May 2012

HAL is a multi-disciplinary open access archive for the deposit and dissemination of scientific research documents, whether they are published or not. The documents may come from teaching and research institutions in France or abroad, or from public or private research centers.
L'archive ouverte pluridisciplinaire HAL, est destinée au dépôt et à la diffusion de documents scientifiques de niveau recherche, publiés ou non, émanant des établissements d'enseignement et de recherche français ou étrangers, des laboratoires publics ou privés. 


\title{
Social studies of volcanology: knowledge generation and expert advice on active volcanoes
}

Amy Donovan ${ }^{1,2}$, Clive Oppenheimer ${ }^{3,4,1}$ and Michael Bravo ${ }^{2}$

(1) Department of Geography, University of Cambridge, Downing Place, Cambridge, CB2 3EN, UK

(2) Scott Polar Research Institute, University of Cambridge, Lensfield Road, Cambridge, CB2 1ER, UK

(3) Le Studium, Institute for Advanced Studies, Orléans and Tours, France

(4) Institut des Sciences de la Terre d'Orléans, University of Orléans, 1a rue de la Férollerie, 45071 Orléans Cedex 2, France

\begin{abstract}
This paper examines the philosophy and evolution of volcanological science in recent years, particularly in relation to the growth of volcanic hazard and risk science. It uses the lens of Science and Technology Studies to examine the ways in which knowledge generation is controlled and directed by social forces, particularly during eruptions, which constitute landmarks in the development of new technologies and models. It also presents data from a survey of volcanologists carried out during late 2008 and early 2009. These data concern the felt purpose of the science according to the volcanologists who participated and their impressions of the most important eruptions in historical time. It demonstrates that volcanologists are motivated both by the academic science environment and by a social concern for managing the impact of volcanic hazards on populations. Also discussed are the eruptions that have most influenced the discipline and the role of scientists in policymaking on active volcanoes. Expertise in volcanology can become the primary driver of public policy very suddenly when a volcano erupts, placing immense pressure on volcanologists. In response, the epistemological foundations of volcanology are on the move, with an increasing volume of research into risk assessment and management. This requires new, integrated methodologies for knowledge collection that transcend scientific disciplinary boundaries.
\end{abstract}

Keywords Social science - Hazards - Risk - Expertise - Advice - Volcanology - Science Studies

\section{Introduction}

'Science and Technology Studies' (STS), 'Social Studies of Science' or 'Sociology of Scientific Knowledge' (SSK) have sought to understand the human context of scientific knowledge development, following on from the works, and debates, of Thomas Kuhn and Karl Popper. 'Science', in its broadest sense, is a very broad term whose meaning is difficult to pin down, and which may be applied to different disciplines by different individuals. Thus, discussing 'science' exposes an author's own conceptualisation of the term (Pedynowski $\underline{2003}$ ), and indeed, STS has been extremely self-conscious in its genesis and applications (Shapin 1995; Jasanoff 1996; Radder 1998; Latour 2004). The social and epistemological study of scientific discourse has been analysed repeatedly by its participants, particularly in relation to politics and the discourse of knowledge - power (Foucault 1980, 1982), in part as they seek to make it 'useful' (Wynne 2007; Webster 2007). It is thus a discipline with multiple metanarratives (narratives existing outside or beyond the historical story), seeking to 
analyse science in its social context, whilst analysing itself and its usefulness to broader science. Inherent in STS is an interdisciplinarity not only in the methods and exegesis of the field itself but also in the field it studies: thus, STS and SSK have discussed the biomedical sciences (Wynne 1989; Jasanoff 2005) and the physical sciences (Traweek 1988; Collins $\underline{2004 a}$ ), in some detail, and have been used in the generation and review of science policy (e.g. Jasanoff 1990; Wynne 1992) - a development which itself has been debated in the ongoing discussion of the nature of STS (Shapin 1995; Irwin 2008). Studies have also addressed historical and geographical contexts in the development of science (e.g. Shapin $\underline{1984}, \underline{1998}$ ) and thus have transcended disciplinary boundaries even as they study them: science has permeated culture to unprecedented levels, with the result that traditional disciplinary studies and even nomenclature are called into question (Lawrence and Després $\underline{2004)}$.

STS or Science Studies provide the preferred nomenclature here, and includes philosophical, anthropological and epistemological studies alongside the sociological (e.g. Irwin and Wynne 1996; Golinski 1992; Wynne 2007; Wynne et al. 2007); it is taken to include SSK. All three nomenclatures are often used synonymously. Science Studies is an interdisciplinary field, encompassing studies grounded in sociological theory about the roles of individuals and organizations (Latour 2005); the law (Jasanoff 1996; Lynch and Cole 2005), where scientific advice is used regularly in forensic science and medicine, among other topics; or in issues of political import, such as bioethics, Bovine Spongiform Encephalopathy (BSE), pollution and global warming (Martello 2004; Jasanoff 2007). Other studies have examined the idea of 'risk governance': how governments identify and manage risk within society, and how that risk must be reduced to a socially acceptable level (De Marchi 2003; Renn 2008). Both of these types of study are fundamentally concerned with the role of the perceived 'expert' in providing governments and local authorities with information from which they can make decisions. This in turn requires an assessment of levels of knowledge: what makes an expert, and how are experts distinguished from the population, particularly in liberal democratic societies, where educated people may be suspicious of hierarchical models?

The link between perception of experts and perception of risk is encountered frequently in risk communication studies: belief in experts has a significant effect on popular interpretation of threats (Haynes 2005; Haynes et al. 2007; Renn 2008), and belief in experts is linked to the perception of science and its methodologies and uncertainties. Science is not inherently democratic, but it has an increasing hold over Western democratic societies, which depend on technologies for their existence (Beck 1992). This creates an uneasy tension, because societal beliefs about science may be very different from those of the scientists themselves, whether the differences are morally based, epistemological or politically motivated, for example. Expertise carries authority, and the designation of that authority by a society may be dependent on education, background, experience, local knowledge and relevance to a particular situation, and different disciplines may be required to work together in what appears to be a very artificial setup. Interdisciplinarity and ways of communicating across disciplines may be extremely important for public safety, but may also be difficult for the scientists themselves to develop (Collins and Evans 2007). It is in this kind of situationwhere scientific advice of different kinds is needed for policymaking - that STS provides valuable insights.

The idea that science and society are 'co-produced' (Jasanoff 2004) hints at the complexity of the relationship between the two, their interdependence and interaction. Even where science claims to be the study of nature, it is still a study, a human activity with correspondingly 
human frameworks. In the aftermath of Bruno Latour's seminal work Science in Action (1987), a body of work has been accumulating, examining knowledge societies: as science has come to dominate many aspects of people's lives, the dependence on technology, coupled with its complexity, has produced social gradients of understanding, reliance and knowledge acquisition. The management of knowledge societies in a political context then involves the regulation of scientific pathways and procedures, producing a dichotomy between science that is application based and science that follows the traditional path of discovery-induced progress. Governance and scientific practice are increasingly linked (e.g. Jasanoff 1990, 2004, 2007), and scientific knowledge enters into a complex relationship with power. Political crises resulting from mismanagement of science, such as BSE, genetic modification and stem cell research, have precipitated greater public regulation of science and its activities. The role of science in the creation and sustenance of social order has increased exponentially in the last 30 years. This study will apply methodologies from STS to volcanology for the first time to examine its development and principles in relation to their social context, and discuss the historical, philosophical and geographical implications for scientific practice. It seeks to elucidate the purpose of volcanology and the reasons that volcanologists embark on their careers. It also deals with the unique nature of volcanology's history and its epistemology: what it might mean to be an expert in volcanology, and how this expertise relates to experiences.

\section{Methods}

This paper is based on a research project that involved three separate methodologies from the social sciences. A survey was circulated via the 'Volcano listserv' in late 2008 and early 2009, asking scientists to give opinions about their discipline. These data have been analysed, and are discussed below. Statistical methods used include factor analysis - a form of principal components analysis that takes eigenvalues of the correlation matrix of the dataset to search for underlying patterns. The analysis seeks to maximize the variance explained by each eigenvector. In factor analysis, a predetermined number of eigenvalues are calculated. In this case, eigenvalues $>1$ were selected, in accordance with Kaiser's criterion (Field 2000). The resulting component matrix is then rotated to ensure ease of interpretation. In this study, a direct oblimin (oblique) rotation was used because it was felt that the factors would correlate (Field 2000). A total of 186 volcanologists responded to the survey, from a wide variety of institutions around the world. Many of them (59.2\%) had experience at a volcano observatory, and just over half (52.9\%) had doctoral qualifications.

Multiple test statistics were calculated for the dataset, investigating the impact of demographic predictor variables on participants' responses. Initially, the distributions were assessed for skewness and kurtosis, which were rated at the 5\% significance level at $z=1.96$ or greater (after Field 2000). Tests of normality were applied, and non-parametric tests performed as necessary. The data discussed in this paper were non-normally distributed, as they reflected strong opinions. Correlation with predictor variables was therefore measured using Spearman's rho, tested at the 5\% significance level (two-tailed test). Cronbach's alpha was used to measure the reliability of scales within the survey.

In addition, interviews were carried out with scientists in the UK, Montserrat, Italy and Iceland during fieldwork seasons. Two 10-week periods of participant observation were carried out at the Montserrat Volcano Observatory in 2008 and 2009, during which petrological data analysis was undertaken. While in the natural sciences quantitative methods are preferred, this pattern is reversed in the social sciences, where qualitative methods are 
generally favoured because they allow for deeper sociological and narratological accuracy. Thus, it was thought appropriate to use both quantitative and qualitative methods in this study.

Key ideas from STS

Social construction and the modes of science

The idea that scientific knowledge production may be at least partially socially constructed is not easily accepted by some scientists. Social constructivism is a minefield of diverse and contradictory accusations, claimed as it is by sociologists and sociologists of science for different and opposed meanings-Hacking (1999) refers to it as 'obscure and overused'. Its interpretation by scientists as a claim that their objectivity was compromised, and by mainstream social science as an assertion that science was weak was met with confusion by sociologists of science (Latour 2005), and generated the so-called 'science wars'. However, its basic tenet in the STS context is that society and nature are engaged in complex interactions by and through which both may be understood (Latour 1987, 2005; Jasanoff 1996). The application of sociology to science may occur in a variety of frameworks, concentrating only on the scientists, or venturing into the cognitive and technical arenas, where the social is considered as a fluid, moving between groups, agents and objects, and indeed facts. It is this sense in which STS applies 'social constructivism' (Metzner-Szigeth 2009). Scientists are often suspicious of social constructivism, because it argues that the personality, social position, interests and abilities of the scientist are closely linked to their production of science. However, it does not argue that there is no objective 'truth', nor that science does not uncover objective truths; it seeks to identify the social connections and movements that participate in the production of science. Latour states that 'objects of science may explain the social, not the other way around' (Latour 2005, p.99).

The importance of collaboration and publication in volcanology, for example, focus scientific discovery in line with mutually beneficial projects. Similarly, public funding for science is socially and politically regulated. That there is an element of social construction in science is therefore hard to dispute, but at the same time, engagement with the natural world brings some objectivity into the subject matter of science, and the historical and geographical controls on the generation of knowledge in volcanology are in part constructed by nature and not by either societies or the social behaviours of scientists. This is a form of co-productionthe natural world and the social world conspire in the production of science. The coproduction of science and social order is similarly reflected in volcanology: volcanology is a relatively young science, particularly in application to eruption forecasting. This has caused problems where populations have expected more from science than science can provide, at the cost of social order and potentially of lives if people refuse to evacuate (e.g. Aspinall and Sparks 2004). This relates very closely to the management of uncertainty, and its communication. A volcano is a substantial agent of social associations, actions and inactions (Aspinall et al. 2002).

STS scholars (Gibbons et al. 1994; Nowotny et al. 2001) have discussed a crude scheme for the classification of science into two modes: mode 1 is traditional, research-based science, whose direction is determined by scientific logic; mode 2 is application-based science, where the next step in scientific process is determined by its social relevance. While the distinction is clearly not as simple as these authors would like, it is nevertheless a helpful framework for discussion. In volcanology, the mode1: mode 2 distinction is seen most clearly in the differences between monitoring and research. It is also undermined by this context in two ways: first, monitoring and research feed into each other; and secondly, research increasingly 
has to be socially justified in order to obtain funding. At the same time, the increase in volcanic hazard science as a sub-discipline of volcanology does suggest an increasing mode 2 component in the production of scientific knowledge. In part, this relates to personal experiences and the pedagogic appropriation of anecdotes in university volcanology courses: shared narratives carry important social lessons specific to volcanic events and represent an attempt to crystallize experience as expertise.

While philosophers of science discuss epistemology in a narrow context, sociologists of science have extended its purview. Jasanoff $(\underline{2005})$ defines 'civic epistemology' as 'the institutionalized practices by which members of a given society test knowledge claims used as a basis for making collective choices': the ways in which societies appraise the claims of experts when these claims are used to make political decisions. This concern relates to the role of scientists within a democracy - as advisors rather than autocrats - and also to the authority of science in society, which may be derived from perceptions of science, of scientists and of the potential impact of any science-based policy on citizens (Jasanoff 2005). The nature of knowledge in the political sphere is much more contentious than in the academic world. While scientific knowledge claims are generally assessed through the peerreview process for their scientific validity and credibility, application to the political context subjects them to a much broader range of tests- which may not be based upon science at all.

\section{What does it mean to be an expert?}

Expertise in modern democratic societies may be regarded as a commodity: governments may use or abuse it; individuals may manipulate it; policies may depend on it to greater and lesser degrees. The consultation of experts is closely linked to the public since it is the public that must suffer the result of expert judgement, and must also trust it even when it is unpalatable (as is often the case in evacuation calls on an active volcano). There is a fundamental change in expertise as soon as it is politicised: the expert becomes vulnerable, and this may suit the authorities if expertise points to controversial policy. Thus expertise in policy decisions is expertise that is monitored by an audience, by consumers - and not necessarily according to its scientific merit. This raises a further point: experts who give advice in policymaking are chosen by someone, and the process of selection may have political, social or personal foundations (Jasanoff 2003; Turner 2001). In volcanology, the experts have often been selfselecting, either by experience in a particular place, or through professional relationships with scientists already involved: advisory structures, as far as they exist in volcanology, have in the past been largely constructed reactively. Increasingly, however, volcano observatories and long-term monitoring projects by academic institutions are providing permanent potential advisory sources dealing in local knowledge. At the same time, there are other international scientists who specialize in crisis management-such as the USGS Volcanic Disasters Assistance Programme (VDAP), which is available for consultation at short notice. A successful example of collaboration between VDAP and local scientists was the eruption of Pinatubo in 1991 (Newhall and Punongbayan 1996).

The ambivalent attitude of the public towards experts and their employment by the government is reflected in calls for contracts between governments and experts, clarifying the role of the latter, and what is expected of them (Weill 2003). It is also reflected in the growth of participatory techniques for involving the public in consultations with experts (Rayner 2003; Leach and Scoones 2004, Leach et al. 2004; Evans and Plows 2007). 'Expertise' is a very broad concept, particularly in the West, where experts are expected to answer questions chosen and posed by those lacking in the expertise that might in fact be fundamental to 
selecting the important questions (Nowotny 2003). In volcanology the questions that are posed by the public are human ones; they are questions not based on science or even directly about it, but questions about survival and everyday life. The ability of scientists to answer them, however, is restricted by the bounds of scientific research and knowledge development (Sparks 2003; Sparks and Aspinall 2004). This is dependent on research interests and also on discrete historical events. Much current knowledge about volcanic risk perception, for example, is the result of research at Etna, Kilauea, Vesuvio, Pinatubo and Montserrat, and other well-known volcanoes (e.g. Gregg et al. 2004; Dominey-Howes and Minos-Minopoulos 2004; Haynes 2005, Haynes et al. 2007; Dibben 2008; Chester et al. 2008; De La Cruz-Reyna and Tilling 2008; Barberi et al. 2008). It hinges on narratives of experience, from specific locations. Nowotny (2003) suggests that expertise is transgressive: its application takes it beyond its theoretical formulation, and adds to it requirements of other kinds of expertiselocal knowledge, for example. It is transgressive, too, in that it must be translated for the public, and thus generates echoes of itself within popular discourses. The moment at which expertise is applied politically, it shifts, and it is vulnerable to attack for reasons other than academic ones, particularly if it is also regarded as alien to local experience, as is the case for communities facing a volcanic threat for the first time.

In 1995, Montserrat became dependent on volcanological expertise almost overnight (e.g. Clay et al. 1999; Pattullo 2000; Druitt and Kokelaar 2002; Aspinall et al. 2002). This placed a great deal of pressure on both scientists and policymakers, as they sought to understand one another. Volcanology incorporates and overlaps with geophysics, seismology, geodesy, sedimentology, fluid dynamics, gas geochemistry, petrology and numerous other aspects of earth science. Within this diverse group are found multiple epistemologies, philosophies and less well defined trends in scientific thought. In addition, the volcanologist may be experienced in multiple fields, as may happen, for example, at an observatory with few staff members. Scientists from different disciplines think in different ways. This can create problems in volcano hazard assessment, because different discourses are brought together in attempts to assess the state of the volcano. There may be misunderstandings and debates concerning the validity of specific techniques, the size of errors, and the many simplifications intrinsic to modelling in both geophysics and geochemistry (e.g. Oreskes et al. 1994). Fundamentally, then, issues of epistemology underlie much scientific debate: how do scientists know what they think they know? In volcanology, this debate is at times of crisis drawn into the public sphere, and scientists must be able to justify their conclusions across disciplines and cultures. This highlights the need to examine and explain volcanology as a discipline with a social context that feeds into it. Responses to social concerns have driven the generation of new approaches to volcanic risk management, for example (e.g. Aspinall et al. 2002). This constitutes an epistemological broadening of the scientific endeavour.

Collins and Evans (2007) introduce a typology of expertises, examining the types of skills needed in providing scientific advice. In particular, following Collins $(\underline{2004 b})$, they discuss 'interactional' expertise and 'contributory' expertise. The former is expertise which enables one to understand a discipline to the point of being able to mediate between experts: a conversant style of expertise. 'Contributory' expertise, on the other hand, is a level of expertise that enables one to participate in research-make a contribution to the field. 'Interactional' expertise, then, might be required by a group leader - or an observatory director - in order to bring together different scientists from a broader area than their own original specialism. It is also required of scientists who are involved in scientific advice-so an advisory committee might be composed of geophysicists, seismologists, petrologists, geochemists and risk analysts, for example, but in order for a report to make sense, at least 
one person has to be able to understand what is said by all of them and be able to translate it for policymakers.

As soon as knowledge is distributed more widely, particularly where it is uncertain, it becomes vulnerable to politically motivated scrutiny. While much of geophysics and geochemistry is, at least at present, largely academic, volcanology cannot remain out of reach of the public because it has relevance for public safety and thus public policy. Its modes of knowing therefore become public and open to criticism as well as respect. In particular locations, volcanology can come under intense scrutiny, both from potential funding bodies and from the public. The way that science is conducted, particularly in crisis situations where government funding is available for monitoring but not research, may be tightly controlled. Knowledge acquisition is thus politicised and socially directed, and the development of research projects may depend on non-local resources.

The eruption on Montserrat was a 'Black Swan' (Taleb 2007) as far as the Montserratian public was concerned, and it transformed the relationship between citizens and science. This relationship is not purely a matter of knowledge, or even of method, but also of epistemology and the nature of uncertainty. STS scholars have demonstrated that science and politics not only mix, but are often inseparable - frequently at the cost of the scientists (Jasanoff 2004; Stirling 2007). Policy analysts, on the other hand, require an entirely different approach to decision making than the scientific community makes internally (e.g. Morgan and Henrion 1990): for example, there is rarely time for peer review in the policy process, especially in a crisis. Approaching science from the outside is a different experience from doing sciencebut both approaches are used by those who use science. This raises important questions about the nature and purpose of science, whilst also pointing to the multiplicity of the answers.

\section{Results and discussion \\ Demographic}

The demographic for the survey is given in Fig. 1. The data were tested for correlations and significant test statistics as described above. It should be noted that there is a significant bias in the demographic in relation to nationality: the bulk of the responses were from Anglophone countries, and this impacts the results below. 

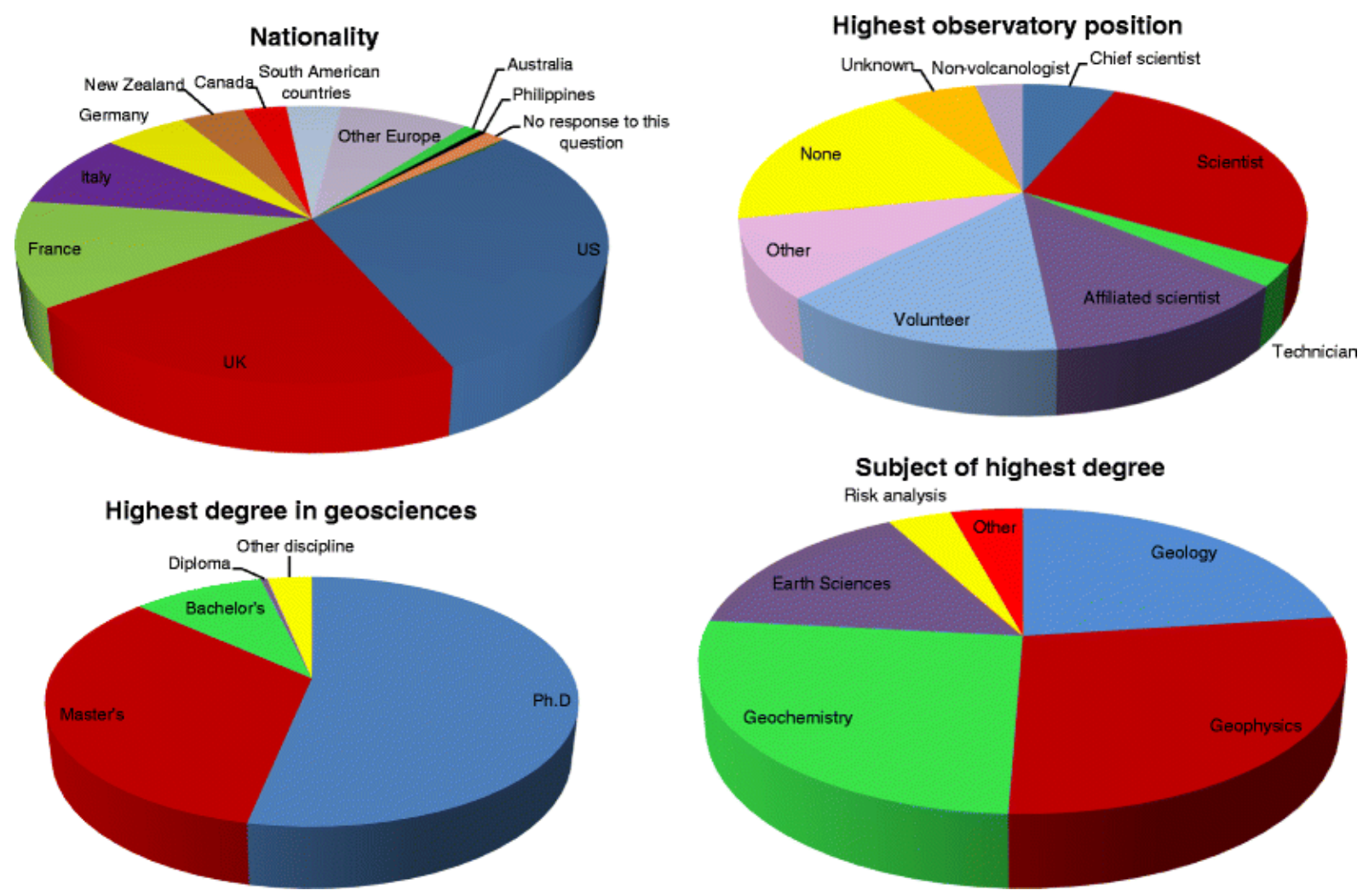

Fig. 1 Survey demographic results

Who does volcanology and why?

The results of the questionnaire concerning epistemological and philosophical foundations for volcanology are given in Table $\underline{1}$. 
Table 1 Opinions of volcanologists concerning statements about their discipline

\begin{tabular}{|l|l|l|l|l|l|l|}
\hline Statement & $\begin{array}{l}\text { Strongly } \\
\text { disagree }\end{array}$ & Disagree & Neither & Agree & $\begin{array}{c}\text { Strongly } \\
\text { agree }\end{array}$ & Unsure \\
\hline $\begin{array}{l}\text { Volcanology is first and foremost } \\
\text { about the study of volcanic } \\
\text { processes }\end{array}$ & 1.20 & 4.79 & 8.98 & 43.71 & 40.72 & 0.60 \\
\hline $\begin{array}{l}\text { Volcanology is important } \\
\text { primarily because volcanoes are } \\
\text { dangerous to human life }\end{array}$ & 1.18 & 16.0 & 30.8 & 33.1 & 18.9 & 0 \\
\hline $\begin{array}{l}\text { Volcanology is primarily an } \\
\text { academic discipline }\end{array}$ & 13.6 & 38.5 & 24.9 & 20.1 & 2.96 & 0 \\
\hline $\begin{array}{l}\text { Volcanology is primarily about } \\
\text { forecasting eruptions }\end{array}$ & 11.2 & 42.6 & 29.0 & 13.0 & 3.55 & 0.59 \\
\hline $\begin{array}{l}\text { All volcanologists should seek } \\
\text { primarily to study processes that } \\
\text { can be linked directly to hazard } \\
\text { assessment }\end{array}$ & 17.7 & 42.9 & 15.9 & 18.8 & 3.53 & 1.18 \\
\hline $\begin{array}{l}\text { Researchers should deliberately } \\
\text { concentrate on understanding } \\
\text { volcanoes near large population } \\
\text { centres }\end{array}$ & 16.0 & 34.9 & 21.9 & 18.3 & 8.28 & 0.59 \\
\hline $\begin{array}{l}\text { Past eruptions have dictated the } \\
\text { progress of volcanology }\end{array}$ & 0 & 2.96 & 14.2 & 52.1 & 27.2 & 3.55 \\
\hline
\end{tabular}

Figures are percent to two decimal places. $N=175$ 
Several of the statements in Table 1 concern moral issues, such as whether or not the potential risk to humanity from volcanoes should provoke deliberately humanitarian approaches to science. It is clear that of the volcanologists who replied to the questionnaire, the majority thought that while volcanologists should not feel obliged to study specific areas at risk or processes that can be linked to hazard assessment, they also had significant concerns for the social application of their science. The demographic data were used to search for meaningful correlations between demographic predictor variables and the statements. The only predictor found to be of significance was level of highest degree. Those with higher degrees were more likely to think that volcanology is primarily academic ( $r h o=0.199$, sig $=0.008)$, and less likely to agree that it is important because volcanoes are dangerous ( $\mathrm{rho}=-0.191$, $\operatorname{sig}=0.011$ ), or that volcanologists should seek to study hazardous processes (rho $=-0.214$, $\operatorname{sig}=0.005)$. Whether a scientist was working in academia or an observatory did not appear to have a significant impact on the results.

A factor analysis was carried out on statements 1 to 6 , which explored the motivations behind volcanology. The results are given in Tables $\underline{2}$ and $\underline{3}$.

Table 2 Factors identified. Cronbach's alpha for normalised scale $=0.616$ (see text for discussion)

\begin{tabular}{|l|l|l|}
\hline Factor & Eigenvalue & \% variance \\
\hline Social (mode 2) & 2.295 & 38.248 \\
\hline Academic (mode 1) & 1.175 & 19.583 \\
\hline Total variance & & 57.832 \\
\hline
\end{tabular}

Table 3 Factor weightings

\begin{tabular}{|c|c|c|}
\hline & Social & Academic \\
\hline Volcanology is first and foremost about the study of volcanic processes & -0.015 & 0.729 \\
\hline $\begin{array}{l}\text { Volcanology is important primarily because volcanoes are dangerous to } \\
\text { human life }\end{array}$ & 0.709 & -0.056 \\
\hline Volcanology is primarily an academic discipline & 0.013 & 0.801 \\
\hline Volcanology is primarily about forecasting eruptions & 0.774 & 0.104 \\
\hline $\begin{array}{l}\text { All volcanologists should seek primarily to study processes that can be } \\
\text { linked directly to hazard assessment }\end{array}$ & 0.837 & -0.020 \\
\hline $\begin{array}{l}\text { Researchers should deliberately concentrate on understanding volcanoes } \\
\text { near large population centres }\end{array}$ & 0.693 & -0.026 \\
\hline
\end{tabular}

Values close to 1 suggest a high weighting to a particular factor

The factor analysis was used to analyse in more detail the links between the answers received, and the identification of two factors, one pertaining to social considerations and the other to pure academia, demonstrates the underlying bimodal pattern. It should be noted, however, that only $58 \%$ of the variance is accounted for; the addition of a further factor would increase this to $72 \%$, and a fourth to $85 \%$. While the additional factors demonstrate some subtletiesnotably that statements 5 and 6 are normative while the first four statements are epistemological — they both require eigenvalues less than 1 ( 0.877 and 0.761 , respectively). 
This is also the reason for the low Cronbach's alpha: the statements are not all measuring the same thing. There is a difference between the direct use of knowledge to ameliorate the impacts of volcanic hazards, and the generation of knowledge that may or may not aid efforts to reduce societal impacts (the complex interface between modes 1 and 2).

Many volcanologists are concerned about moral issues, such as whether the potential risk to human life from volcanoes should provoke deliberately humanitarian approaches to science. It is clear that of the volcanologists who replied to the questionnaire, the majority thought that while volcanologists should not feel obliged to study specific areas at risk or processes that can be linked to hazard assessment, they also had significant concerns for the social application of their science. While many feel that volcanology gains some of its importance from the hazard that volcanoes pose to human life, they are less keen to see the directions of research pushed into either areas or processes that are particularly relevant to public safety. Similarly, the importance of forecasting eruptions is not rated very highly. This may be indicative of the complex relationship between understanding volcanoes and forecasting their activity, the latter being regarded perhaps as a statistical question, and the former deterministic. It should also be noted that those who participated in the survey may have been more likely to be interested in social scientific studies, and therefore the social application of volcanology: the results do not necessarily represent the volcanological community as a whole. They are consistent, however, with the context of the IAVCEI Subcommittee for Crisis Protocols (1999) and the replies to it: there is an underlying tension between socially driven and academically driven studies and behaviours.

Volcanologists who participated in the questionnaire were also asked why they became volcanologists in the first place. There were two groups of answers to this question. The first concerns the opportunities in volcanology 'to put science training to immediate humanitarian benefit': a desire to help society in some way. The other group was focussed on the natural majesty of volcanism and the processes involved - respondents mentioned climbing volcanoes as a child, for example. Some answers straddle the groups - people who had become involved in monitoring an eruption at some stage in their career, and people who had been born in areas close to active volcanoes. This suggests that experience of volcanoes, either as powerful and impressive natural features or as threatening to populated areas, is a major factor in drawing people into the science. This was also reflected in the testimony of one senior scientist who stated that he had originally entered the field purely out of scientific interest but had been drawn into hazard assessment because of what he had seen in local communities affected by volcanism. Disaster management officials on Montserrat noted that they had been touched by intervention from scientists regarding the squalid conditions of the shelters provided by the British government in the early years of the eruption, and said that although this was not the role of scientists, a letter to a newspaper had clearly had an impact on British policy. Several scientists interviewed described local connections, either on Montserrat or elsewhere, and a lingering influence of these places on their research interests.

There is thus an economy between experience and expertise, with the one leading into the other. Experience can drive research interests and thus the progression of knowledge. Volcanologists were also asked to list some of their most seminal experiences in the field, and for many these were closely linked with a deep passion for the subject. In some cases, the exhilaration of being on an active volcano triggered the desire to know more and study hard. In others, the effect of seeing the consequences of eruptions for local populations alongside their potential avoidance shifted academic careers into the realms of hazard and risk assessment. In particular, the frustration of trying to manage populations whilst dealing with 
high levels of scientific uncertainty was mentioned by a number of scientists. It would appear from their observations that volcanologists are highly motivated both by scientific discovery and interest and by social concerns.

The helpful distinction between 'mode 1' and 'mode 2' in Science Studies (Gibbons et al. 1994) may be applied to this juxtaposition of concerns for academic and field science in conjunction with social application: volcanologists hold firmly to the academic importance of volcanology, and the physical and chemical processes that they study, but simultaneously, many hope that the application of the science will make a difference to vulnerable societies, and a significant number deliberately seek to study aspects or areas that are directly relevant to hazard assessment and vulnerable populations.

"One thing for sure is that scientists have to also consider societal demands and we have a moral obligation to try to make sure that one of the consequences of volcanological research or earth science research is that we can apply some of those results to try to answer some questions that society has, and I really see volcanology as a multidisciplinary science that is really bridging this gap between fundamental science and applied science."

The distinction between modes 1 and 2 in volcanology is therefore non-dichotomous for many scientists: purely academic breakthroughs can aid hazard assessment, and some people view volcanology itself as a bridge between science and society. However, in recent years funding has been made available for specific hazard-relevant projects, such as Multidisciplinary Monitoring, Modelling and Forecasting of Volcanic Hazard, Explosive Eruption Risk and Decision Support for EU Populations Threatened by Volcanoes, Mitigate and Assess Risk from Volcanic Impact and Network for Observation of Volcanic and Atmospheric Change (e.g. Neri et al. 2008; Baxter et al. 2008; Galle et al. 2010), funded by the EU-and probabilistic risk assessment is very much at the heart of recent EU funding calls. Scientists interviewed for this project also expressed some concern at this: 'hazard' had become a buzz word, used by academics to obtain funding at the expenses of pure science. On the other hand, the funding gap between university scientists and observatory scientists around the world suggests that there is considerable disparity, with observatory scientists often earning less, publishing less and having fewer resources, although there is considerable geographical variability. All the volcanologists interviewed expressed awareness of a dichotomy between monitoring and research, which is compounded by perceived disparities in funding - though again, this varies significantly with location.

While the use of 'hazard' and 'risk' as buzz words for the justification of research is frustrating within the academic community, it also reflects a growing democratization of science more generally (Fischer 2010): ensuring that science is socially useful is high on the public agenda. At the same time, a movement towards the development of risk assessment tools, such as Bayesian Event Trees and Expert Elicitation procedures has come from within volcanology, as experts are increasingly aware of both their liability and responsibility, and the uncertainty of their knowledge under social interrogation (Newhall and Hoblitt 2002; Aspinall et al. 2003; Marzocchi et al. 2004; Aspinall 2006, 2010; Neri et al. 2008). This has been described as a 'paradigm shift' by Baxter et al. (2008). It also has civic epistemological implications within the volcanological community, as the directions of research respond both to past eruption experiences — such as Montserrat - and to socially derived issues such as population growth on active volcanoes.

\section{Histories of volcanology: discrete events?}


Responses to the seventh statement in Table 1 were highly congruent, with $79.3 \%$ agreeing or strongly agreeing that past eruptions have dictated the progress of volcanology. This is perhaps unsurprising: it parallels the progression of technological development in wartime, and reflects the imperative to advance. It also demonstrates the importance of observation in volcanology, and the empirical confirmation of models. While methods of reconstruction of volcanic eruptions from the geological record are increasingly informative, there remain types of eruption that have not been witnessed within the modern era, the most dramatic being a socalled 'super-eruption'. One interviewee noted that in 1997, when 19 people were killed on Montserrat, "we were seeing phenomena that people had never seen before, the re-forming of pyroclastic flows, having flowed into the valley...went up the hill, over their houses, and then it just under gravity came back down, re-formed, and came along the Belham River valley'. The impact of these events on the scientists involved has had a significant impact on their subsequent careers - and for many, a continued interest in Montserrat. Eruptions may be regarded as 'epistemological acts' (Bachelard, cited in Foucault 1968): they alter the course of volcanological knowledge production.

The survey asked volcanologists to list those eruptions that they felt had most contributed to modern volcanology. The results are given in Table $\underline{4}$.

Table 4 Volcanologists' answers to the question, 'Which eruption(s) do you think have contributed most to modern volcanological thinking?' 


\begin{tabular}{|l|l|}
\hline Eruption & $\begin{array}{l}\text { Number } \\
\text { of votes }\end{array}$ \\
\hline Mount St. Helens (1980) & 114 \\
\hline Mount Pinatubo (1991) & 68 \\
\hline Soufrière Hills Volcano, Montserrat (1995-) & 49 \\
\hline Kỉlauea (recent) & 35 \\
\hline Etna (recent) & 19 \\
\hline Nevado del Ruiz (1985) & 18 \\
\hline Mount Pelée (1902) & 17 \\
\hline Mount Vesuvius (AD 79) & 14 \\
\hline Mount Unzen (1991) & 12 \\
\hline Stromboli (recent) & 11 \\
\hline Mauna Loa (recent) & 10 \\
\hline Krakatau (1883) & 10 \\
\hline \begin{tabular}{l} 
El Chichón (1982) \\
\hline Redoubt (recent)
\end{tabular} & 8 \\
\hline Galeras (1993) & 6 \\
\hline Katmai (1912) & 6 \\
\hline Bishop Tuff (0.76 Ma) & 3 \\
\hline Surtsey (1957) & 3 \\
\hline Guadeloupe (1976) & 3 \\
\hline Paricutin (1943) & 2 \\
\hline Taupo (65000 BP to present) & 2 \\
\hline Mount Augustine (recent) & 2 \\
\hline Bezymianny (1956) & 2 \\
\hline Gjálp (1996) & 2 \\
\hline Laki (1783) & 2 \\
\hline Yellowstone (0.64 Ma) & \\
\hline $\begin{array}{l}\text { Other volcanoes mentioned individually: Santorini (historical), Campi Flegrei } \\
\text { (recent unrest), Tungurahua (recent), Shishaldin (recent), Capelinhos (1957), } \\
\text { Krafla (1975), Lake Nyos (Oku volcanic field, 1986), Popocatépetl (recent), } \\
\text { Mount Spurr(1953, 1992), Arenal (recent), Mount Lamington (1951), Sakurajima } \\
\text { (recent), Rabaul (recent), Deccan Traps (flood basalt), Valles caldera } \\
\text { (Pleistocene), Mount Fuji (historical), Tambora (1816), Piton de la Fournaise } \\
\text { (recent) }\end{array}$ & 1 \\
\hline & \\
\hline
\end{tabular}

One of the key aspects of Table $\underline{4}$ is the absence of the non-eruptions. Only two respondents named Guadeloupe, 1976, as a key event, one with a comment 'Soufriere of Guadeloupe, 1976, as the end of dark ages, then Mount St Helens, 1980, as the spark and light of modern ages' (Bostok 1978; Fiske 1984). One other noted the importance of 'non-eruptions', and 
other non-eruptions or recent unrest that were noted as significant were Campi Flegrei and Vesuvio. It could further be argued that hazardous events - such as catastrophic landslidescan occur at volcanoes that are not currently active. In part this is due to the phraseology of the question, which asked for significant 'eruptions' - and the wideness of this term is evident in the mention of Lake Nyos, for example, which was non-magmatic: different respondents interpreted the question differently. If the question had to be rephrased, however, it is unclear how to do so without creating other biases - using the term 'non-eruption' might overemphasise the importance of these events relative to the data-generating eruptions. A further bias in the results is the aforementioned geographical distribution of respondents - many were from the UK and USA (see Fig. 1) - and their position in the broader history of volcanology since the survey asked about the impact on modern thinking.

Comments emphasise the importance of a change in thinking - interestingly in how 'geologists viewed volcanology': volcanology is framed as a sub-discipline of geology. It is clear that there is a high regard for specific events, but a recognition that the usefulness of an event depends on it being either well known (communicated and reported) and/or well monitored (generated a lot of data). A number of scientists noted that their view may be biased because of their own experiences and involvement, or because of their nationalityAmericans were particularly conscious of over-emphasising Mount St. Helens, although many non-Americans highlighted that eruption as important. It is also clear that volcanologists are very aware of the differences between volcanoes and the problems of comparison. They also comment on the problem of the individual: experience has been shown to affect judgement, and this seems to be a recurrent concern in the notes to this and other questions. Experience, though, is also very highly prized. The act of learning through presence and activity is an important part of the job for many volcanologists. Fieldwork is extremely important, and earns respect and value. The experience of decision making is also prized, but herein lies a challenge: how to document experience so that the community and not solely the individual can benefit from it. The timescale of eruptive crises, and that of the individual career, may not be conducive to having experienced volcanologists to deal with any given emergency.

Also recognised by the volcanologists is the developmental dependence of their work: those countries that lack resources cannot learn from volcanic eruptions to the same extent as those that have the manpower and equipment. This is a fundamental problem for observatories in poorer countries, and necessitates active collaboration with scientists from richer countries, although this can be complicated by differing research agendas (Donovan et al. 2011). Some scientists expressed the view that academic researchers ought to be proactive in sharing resources with observatories, but at the same time others expressed deep frustration with observatories - particularly those observatories in developed countries-failing to appreciate their efforts, or imposing unreasonable data licences. There is evidence that working in developing countries rather than developed ones may be more lucrative for researchers as a result of this 'data licensing'.

Volcanologists clearly thus regard their discipline as highly geographically and historically controlled, directed and mediated. Eruptions are very greatly valued, which creates conflicts of emotion in the event of a disaster, as data gathering and social needs start to come into conflict. One further point to note about Table $\underline{4}$ is that historical eruptions are extremely important, more so, interestingly, than those of even the recent geological past (prior to historical records): the eruptions of Vesuvius in AD 79, and Krakatau in 1883, Laki in 1783 and Pelee in 1902 are all cited many times, yet no monitoring data exist for them. They have become infamous firstly in narrative, rather than in geology - and that then led to scientific 
interest and investment. Thus, Yellowstone, Valles, the Bishop Tuff and similarly wellresearched eruptions (and deposits) are apparently much less important in shaping current thinking. This is backed up too by the regular mention of historical data in the journals, and in other parts of the questionnaire.

The curiously discrete-yet-continuous history of volcanology also feeds into the mode 1: mode 2 dichotomy, and into narratives of expertise and experience. The questionnaire also asked volcanologists to mention those scientists who had most inspired them, and the experiences that had had most influenced them during their careers. Many of the names that recurred were volcanologists who combine extensive field experience in eruption crises with strong academic records. Another comment that recurred was the importance of people with gifts in the communication of volcanology, either within the discipline as teachers, or beyond it to the public, and also those who could 'keep their heads in a crisis'. The willingness to help the public was repeated as an important factor and influence. A significant proportion of these answers referred to human qualities, as well as scientific prowess: those with 'a strong mix of science and humanity' received many accolades. The ability to combine good science with compassionate outreach is highly prized, again testifying to the blurring of modes 1 and 2 in volcanology.

The question about seminal experiences in the field drew a variety of response types. Many people listed dramatic volcanic activity that they had witnessed, and there were many references to living with volcanoes, or meeting people who did so. There was also an element of adrenalin-seeking - people admitted to doing things that with hindsight seemed inadvisable, but which they had enjoyed at the time. Some comments were sobering.

"From this experience, I recognised the psychological phenomena that takes effect when scientists work in dangerous situations - everyone wants to be involved, to come home with the data, to be a valued part of the programme. This can lead people to take unnecessary risks. I also learned that every person must be willing to stand back and analyse the risk - and to recognise that each person has a different threshold of acceptable risk. Their decisions should be honoured by their colleagues and supervisors."

The social context of science - and crisis advisory processes - is thus a key part of the construction of scientific research and involvement. Volunteer work had also had significant impacts on people at early stages in their careers, highlighting the importance of observatory volunteer programmes for 'capturing' keen young volcanologists. Volcanology, then, involves a complex combination of expertise, experience and humanity.

\section{Conclusions}

Popper wrote that 'If we ignore what other people are thinking, or have thought in the past, then rational discussion must come to an end, though each of us may go on happily talking to himself' (Popper 1963). Communication between volcanologists is clearly crucial in a crisis. Yet it is also crucial for the progression of science, to prevent the duplication of research, and to disseminate existing research appropriately. There is, at times, an uneasy but unsurprising tension between the social application of volcanology at observatories, and the priorities of the research community. Volcanology is simultaneously an academic subject and a vocational one, and many careers involve work in both monitoring and research, often at the same time. The results of the survey demonstrate that there is a considerable felt responsibility to pursue 
work that is relevant to the public good, whilst ensuring that the work is 'good science'. For many scientists, the history of volcanology is inextricably linked to field experiences and eruptions but also has a strong academic tradition. The progression of scientific knowledge in volcanology is therefore closely linked to past eruptions, controlled by the planet itself, as well as by human choices. It is also relational: many people who responded to the questionnaire did list their mentors and those who had inspired them to do further research or to get involved in other ways. There is a strong sense of community in volcanology, exemplified best perhaps in the Volcano listserv itself.

Expertise and experience are both sought after in policymaking circles. Selection processes for advisory committees in the UK and the USA are often based on a combination of the two (Jasanoff 1990). In volcanology, experience in crisis management in particular is limited and can rarely be planned. The role of volcanologists in crises is also a matter for debate: the extent to which risk assessment and risk management overlap, for example, which may be clearer in other fields, is often a difficulty in volcanic events. While modern societies depend fairly continuously on energy, biotechnologies and so on, dependence on volcanology may happen very quickly and very intensely, as was the case on Montserrat. The relative infrequency of volcanic crises means that the importance of anecdotal information based on individuals' experiences, may be very high in informing the next generation. Expertise in volcanology takes many forms and involves different subdisciplines. This can be confusing to policymakers, particularly in a crisis (one Montserratian official, and poet, referred to 'custom-made ologists' in a poem about the eruption; Fergus 2003). It can also result in miscommunications among scientists, and in combination with the high levels of scientific uncertainty that are typical of volcanic unrest, achieving a single voice for political advice can be challenging. In response to this, volcanologists on Montserrat began to use statistical elicitation models to estimate the probabilities of particular events (Aspinall et al. 2002; Aspinall 1998, 2006, 2010). While this is highly subjective, it offers a methodology for synthesizing consensus - and it is an example of experience-based expertise.

Transdisciplinary studies may be defined as those that transgress the boundaries of scientific disciplines, involving extra-scientific input for the purpose of solving a problem (Balsiger 2004; see Table 5). Gibbons et al. (1994) described mode 2 science as science with a transdisciplinary approach: it includes both scientific disciplines and contributions from the public and political spheres (and indeed from 'tacit', local knowledges). This is witnessed in decision making on active volcanoes, as scientists, social scientists and local officials seek to work together, often in constant dialogue. The nature of transdisciplinary practice in volcanic eruption management is complicated by the high stakes and differing perceived value of expertises, experiences and techniques. Volcano hazard science is inherently transdisciplinary, requiring an approach that invokes aspects of the different disciplines in a structured whole, which may have both qualitative and quantitative outcomes (Horlick-Jones and Sime 2004). It also includes, crucially, local knowledge and experience-derived knowledge, both of which are highly geographically and historically defined. This inevitably opens up transdisciplinary practices to criticism, since the question of what to include, both in terms of data and of disciplines, and who to listen to, is asked both by participants and by the publics that they serve. 
Table 5 Clarification of definitions

\begin{tabular}{|l|l|}
\hline Term & Meaning in this article (adapted from Balsiger 2004) \\
\hline Interdisciplinary & Collaboration between disciplines to solve a scientific problem \\
\hline Multidisciplinary & $\begin{array}{l}\text { Different disciplines working on a thematic project with no intention of } \\
\text { problem solving }\end{array}$ \\
\hline Transdisciplinary & $\begin{array}{l}\text { Collaboration to solve a scientific problem including the involvement of the } \\
\text { people who are affected by the problem, and therefore involving extra- } \\
\text { scientific (non-disciplinary) input (e.g. from politicians) }\end{array}$ \\
\hline
\end{tabular}

Acknowledgements AD acknowledges a NERC-ESRC PhD studentship. The authors would like to thank Chris Newhall and Augusto Neri for very thorough and helpful reviews, which significantly improved the manuscript.

\section{References}

Aspinall, W. P. (1998). Expert judgement and the Montserrat volcano eruption. In: Mosleh, A. Bari, R. A. (eds) Proceedings of the 4th International Conference on Probabilistic Safety Assessment and Management PSAM4, New York City, 13-18 September 1998. pp. 2113-2118

Aspinall WP (2006) Structured elicitation of expert judgement for probabilistic hazard and risk assessment in volcanic eruptions. In: SCHM Mader, C Connor, L Connor (eds) Statistics in volcanology, 1. Geological Society, London. pp. 15-30

Aspinall WP (2010) A route to more tractable expert advice. Nature 463:294-295

Aspinall W, Sparks RSJ (2004) Volcanology and the law. IAVCEI News 1:4

Aspinall WP, Loughlin SC, Michael FV, Miller AD, Norton GE, Rowley KC, Sparks RSJ, Young SR (2002) The Montserrat Volcano Observatory: its evolution, organization, role and activities. Geol Soc Lond Mem 21(1):71-91

Aspinall WP, Woo G, Voight B, Baxter PJ (2003) Evidence-based volcanology: application to eruption crises. J Volcanol Geotherm Res 128:273-285

Balsiger PW (2004) Supradisciplinary research practices: history, objectives and rationale. Futures 36(4):407-421

Barberi F, Davis MS, Isaia R, Nave R, Ricci T (2008) Volcanic risk perception in the Vesuvius population. J Volcanol Geotherm Res 172(3-4):244

Baxter PJ, Aspinall WP, Neri A, Zuccaro G, Spence R, Cioni R, Woo G (2008) Emergency planning and mitigation at Vesuvius: a new evidence-based approach. J Volcanol Geotherm Res 178(3):454 
Beck U (1992) Risk society: towards a new modernity. Sage, New Delhi (German original, 1986)

Bostok D (1978) Editorial: a deontological code for volcanologists? J Volcanol Geotherm Res 4(1-2):1

Chester DK, Duncan AM, Dibben CJL (2008) The importance of religion in shaping volcanic risk perception in Italy, with special reference to Vesuvius and Etna. J Volcanol Geotherm Res 172(34):216-228

Clay EB, Barrow C, Benson C, Dempster J, Kokelaar BP, Pillai N, Seaman J (1999) An evaluation of HMG's response to the Montserrat volcanic emergency. Department for International Development, London

Collins H (2004a) Gravity's shadow: the search for gravitational waves. University of Chicago Press, Chicago

Collins $\mathrm{H}$ (2004b) Interactional expertise as a third kind of knowledge. Phenomenol Cogn Sci $3(2): 125-143$

Collins H, Evans R (2007) Rethinking expertise. University of Chicago Press, Chicago

De la Cruz-Reyna S, Tilling RI (2008) Scientific and public responses to the ongoing volcanic crisis at Popocatépetl Volcano, Mexico: importance of an effective hazards-warning system. J Volcanol Geotherm Res 170(1-2):121-134

De Marchi B (2003) Public participation and risk governance. Sci Public Policy 30(3):171-176

Dibben CJL (2008) Leaving the city for the suburbs - the dominance of 'ordinary' decision making over volcanic risk perception in the production of volcanic risk on Mt Etna, Sicily. J Volcanol Geotherm Res 172(3-4):288

Dominey-Howes D, Minos-Minopoulos D (2004) Perceptions of hazard and risk on Santorini. J Volcanol Geotherm Res 137:285-310

Donovan A, Oppenheimer C, Bravo M (2011) Rationalising a crisis through literature: Montserratian verse and the descriptive reconstruction of an island. J Volcanol Geotherm Res 203(3-4):87-101

Druitt TH, Kokelaar BP (eds) (2002) The eruption of the Soufriere Hills Volcano, Montserrat, from 1995 to 1999. Geological Society of London, London

Evans R, Plows A (2007) Listening without prejudice? Re-discovering the value of the disinterested citizen. Soc Stud Sci 37:827-853

Fergus HA (2003) Volcano verses. Peepal Tree, Leeds

Field A (2000) Discovering statistics using SPSS. Sage, London 
Fischer F (2010) Democracy and expertise: reorienting policy inquiry. Oxford University Press, Oxford

Fiske R (1984) Volcanologists, journalists and the concerned local public: a tale of two crises in the Eastern Caribbean. Explosive volcanism: inception, evolution and hazards. National Academy Press, Washington

Foucault M (1968) The archaeology of knowledge. Routledge, Abingdon

Foucault M (1980) Power/Knowledge: selected interviews and other writings, 1972-1977. Pantheon, New York

Foucault M (1982) The subject and power. Crit Inq 8(4):777-795

Galle B, Johansson M, Rivera C, Zhang Y, Kihlman M, Kern C, Lehmann T, Platt U, Arellano S, Hidalgo S (2010) Network for Observation of Volcanic and Atmospheric Change (NOVAC); a global network for volcanic gas monitoring: network layout and instrument description. J Geophys Res 115(D5):D05304

Gibbons M, Limoges C, Nowotny H, Schwartzman S, Scott P, Trow M (1994) The new production of knowledge: the dynamics of science and research in contemporary societies. Sage, London

Golinski J (1992) Science as public culture: chemistry and enlightenment in Britain, 1760-1820.

Cambridge University Press, Cambridge

Gregg CE, Houghton BF, Johnston DM, Paton D, Swanson DA (2004) The perception of volcanic risk in Kona communities from Mauna Loa and Hualalai volcanoes, Hawaii. J Volcanol Geotherm Res 130:179-196

Hacking I (1999) The social construction of what? Harvard University Press, Cambridge

Haynes K (2005) Exploring the communication of risk during a volcanic crisis: a case study of Montserrat, West Indies. Unpublished Ph.D. thesis, University of East Anglia

Haynes K, Barclay J, Pidgeon N (2007) The issue of trust and its influence on risk communication during a volcanic crisis. Bull Volcanol 70(5):605-621

Horlick-Jones T, Sime J (2004) Living on the border: knowledge, risk and transdisciplinarity. Futures 36(4):441

IAVCEI Subcommittee for Crisis Protocols (1999) Professional conduct of scientists during volcanic crises. Bull Volcanol 60:323-334, comment and reply in Bull Volcanol 62: 62-64

Irwin A (2008) In: Hackett EJ, Amsterdamska O, Lynch M, Wajcman J (eds) STS perspectives on scientific governance. The Handbook of Science and Technology Studies, 3rd edn. MIT Press, Cambridge, pp 583-608

Irwin A, Wynne B (eds) (1996) Misunderstanding science? The public reconstruction of science and 
technology. Cambridge University Press, Cambridge

Jasanoff S (1990) The Fifth Branch: science advisors as policymakers. Harvard University Press, Cambridge

Jasanoff S (1996) Beyond epistemology: relativism and engagement in the politics of science. Soc Stud Sci 26(2):393-418

Jasanoff S (2003) (No?) Accounting for expertise. Sci Public Policy 30(3):157-162

Jasanoff S (ed) (2004) States of knowledge: the co-production of science and social order. Routledge, Abingdon

Jasanoff S (2005) Designs on nature: science and democracy in Europe and the United States.

Princeton University Press, Princeton

Jasanoff S (2007) Technologies of humility. Nature 450:33

Latour B (1987) Science in action: how to follow scientists and engineers through society. Harvard University Press, Cambridge

Latour B (2004) Politics of nature: how to bring the sciences into democracy. Harvard University Press, Cambridge

Latour B (2005) Reassembling the social: an introduction to Actor-Network Theory. Oxford University Press, Oxford

Lawrence RJ, Després C (2004) Futures of transdisciplinarity. Futures 36(4):397

Leach M, Scoones I (2004) In: Leach M, Scoones I, Wynne B (eds) Science and citizenship in a global context. Science and citizens: globalisation and the challenge of engagement. Zed Books, London

Leach M, Scoones I, Wynne B (eds) (2004) Science and citizens: globalisation and the challenge of engagement. Zed Books, London

Lynch M, Cole S (2005) Science and technology studies on trial: dilemmas of expertise. Soc Stud Sci 35:269-311

Martello M (2004) Global change science and the Arctic citizen. Sci Public Policy 31(2):107-115

Marzocchi W, Sandri L, Gasparini P, Newhall C, Boschi E (2004) Quantifying probabilities of volcanic events: the example of volcanic hazard at Mount Vesuvius. J Geophys Res 109:201

Metzner-Szigeth A (2009) Contradictory approaches? On realism and constructivism in the social sciences research on risk, technology and the environment. Futures 41:156-170 
Morgan MG, Henrion M (1990) Uncertainty: a guide to dealing with uncertainty in quantitative risk and policy analysis. Cambridge University Press, Cambridge

Neri A, Aspinall WP, Cioni R, Bertagnini A, Baxter PJ, Zuccaro G, Andronico D, Barsotti S, Cole PD, Esposti-Ongaro T, Hincks TK, Macedonio G, Papale P, Rosi M, Santacroce R, Woo G (2008) Developing an Event Tree for probabilistic hazard and risk assessment at Vesuvius. J Volcanol Geotherm Res 178(3):397

Newhall C, Hoblitt RP (2002) Constructing event trees for volcanic crises. Bull Volcanol 64:3-20

Newhall C, Punongbayan R (1996) In: Scarpa R, Tilling RI (eds) The narrow margin of successful volcanic-risk mitigation. Monitoring and mitigation of volcano hazards. Springer, New York, pp 807832

Nowotny H (2003) Dilemma of expertise: democratising expertise and socially robust knowledge. Sci Public Policy 30(3):151-156

Nowotny H, Scott P, Gibbons M (2001) Re-thinking science: knowledge and the public in an age of uncertainty. Polity Press, Cambridge

Oreskes N, Shrader-Frechette K, Belitz K (1994) Verification, validation, and confirmation of numerical models in the earth sciences. Science 263(5147):641-646

Pattullo P (2000) Fire from the mountain: the tragedy of Montserrat and the betrayal of its people. Constable, London

Pedynowski D (2003) Science(s) which, when and whose? Probing the metanarrative of scientific knowledge in the social construction of nature. Prog Hum Geogr 27:735-752

Popper K (1963) Towards a rational theory of tradition Conjectures and refutations: the growth of scientific knowledge. Routledge, London (original lecture, 1949)

Radder H (1998) The politics of STS. Soc Stud Sci 28(2):325-331

Rayner S (2003) Democracy in the age of assessment: reflections on the roles of expertise and democracy in public-sector decision making. Sci Public Policy 30(3):163-170

Renn O (2008) Risk governance. Earthscan, London

Shapin S (1984) Pump and circumstance: Robert Boyle's literary technology. Soc Stud Sci 14:481-520 Shapin S (1995) Here and everywhere: sociology of scientific knowledge. Annu Rev Sociol 21:289-321 Shapin S (1998) Placing the view from nowhere: historical and sociological problems in the location of science. Trans Inst Br Geogr 23(1):5 
Sparks RSJ (2003) Forecasting volcanic eruptions. Earth Planet Sci Lett 210:1-15

Sparks RSJ, Aspinall W (2004) Volcanic activity: frontiers and challenges in forecasting, prediction and risk assessment. The state of the planet: frontiers and challenges in Geophysics. Geophysical Monograph 150; IUGG Volume 19

Stirling A (2007) Risk, precaution and science: towards a more constructive policy debate. EMBO Rep 8(4):309-315

Taleb NN (2007) The black swan: the impact of the highly improbable. Allen Lane, London

Traweek S (1988) Beamtimes and lifetimes: the world of high-energy physicists. Harvard University Press, Harvard

Turner S (2001) What is the problem with experts? Soc Stud Sci 31(1):123-149

Webster A (2007) Crossing boundaries: social science in the policy room. Sci Tech Hum Values 32(4):458-478

Weill C (2003) Expert and public consultation: can consultation of both experts and the public help developing public policy? Some aspects of the debate in France. Sci Public Policy 30(3):199-203

Wynne B (1989) Sheepfarming after Chernobyl: a case study in communicating scientific information. Environment 31(2):33-39

Wynne B (1992) Uncertainty and environmental learning: reconceiving science and policy in the preventive paradigm. Glob Environ Chang 2(2):111-127

Wynne B (2007) Dazzled by the mirage of influence? STS-SSK in multivalent registers of relevance Science. Technol Hum Values 32(4):491-503

Wynne B, Felt U, Callon M, Gonçalves M, Jasanoff S, Jepsen M, Joly P-B, Konopasek Z, May S, Neubauer C, Rip A, Siune K, Stirling A, Tallacchini M (2007) Taking European knowledge society seriously. Expert Group on Science and Governance, Brussels, European Commission D-G Research, Science Economy and Society Directorate 